\title{
Indicators of Parental Engagement and Health Promotion Behaviour in Caring for Children with Avoidant Restrictive Food Intake Disorder
}

\author{
Yoyok Bekti Prasetyo ${ }^{1}$, Fransiska Pramaisela ${ }^{2}$, Nur Lailatul Masruroh ${ }^{2}$, Nursalam ${ }^{3}$, Rahmat Hargono $^{4}$, Ahsan $^{5}$ \\ ${ }^{1}$ Doctoral Student, Faculty of Public Health, Universitas Airlangga; ${ }^{2}$ Faculty of Health Sciences, Universitas \\ Muhammadiyah Malang; ${ }^{3}$ Professor, Faculty of Nursing, ${ }^{4}$ Faculty of Public Health, Universitas Airlangga, \\ Surabaya, Indonesia; ${ }^{5}$ Nursing Studies, Medical Faculty, Universitas Brawijaya Malang
}

\begin{abstract}
Introduction: Parental engagement in caring for children is very important and parents must have the ability to care for their children. Health promotion behavior efforts can be made by giving the child a good diet with balanced nutrition. The purpose of this study was to analyze indicators of parental engagement and health promotion behavior in caring for children with avoidant restrictive food intake disorder.
\end{abstract}

Method: This study was a cross-sectional design by simple random sampling with a sample size of 245 participants. The independent variables were parenteral engagement indicators and the dependent variable was health promotion behavior indicators. Data were collected using: a demographic questionnaire, parental engagement questionnaire, and health promotion questionnaire. The analysis used a simple linear regression test with a significance level of $\alpha \leq 0.05$.

Results: Parental engagement can be influenced by parents' age and health promotion behavior was influenced by the level of parental education, number of children and condition of the child. The results of simple linear regression test obtained significance results of 0.000 ( $p$-Value $<0.05$ ), which means that there was a significant influence of parental engagement on promotive behavior.

Conclusion: Good parental engagement and health promotion behavior will reduce tension when providing care for children with Avoidant Restrictive Food Intake Disorder. When the stress of parents decreases, parents will be able to be more sensitive to read signals from their children.

Keywords: parental engagement, health promotion, avoidant restrictive food intake disorder.

\section{Introduction}

Engagement between parents in caring for children is very important. Father's role in parenting involves physical, affective and cognitive processes in the interaction between father and child ${ }^{1}$. The involvement of fathers is very important for child development in several aspects, such as assisting in child feeding ${ }^{2}$, accompanying children to play and learn and in helping children while learning about toileting ${ }^{3}$. Fathers also

\section{Corresponding Author:}

\section{Nursalam}

Professor, Faculty of Nursing, Universitas Airlangga,

Surabaya, 60115, Indonesia

Email:nursalam@fkp.unair.ac.id play a role in providing solutions to the difficulties experienced by their children ${ }^{4,5}$. A father, in carrying out his parenting role, needs to have fathering skills so that he can educate and nurture children to the maximum ${ }^{6,7}$. The obstacles in establishing engagement are accepting a different perspective from others. Parents tend to resist attempts to change their minds, especially when they are in conflict situations ${ }^{8}$.

Avoidant restrictive food intake disorder (ARFID) is a new term for describing infant and toddler age disorders with such characteristics as refusing to eat; poor mealtimes; low eating skills that are not in accordance with the child's development stage ${ }^{9}$; lack of interest in eating; avoidance based on sensory food, including appearance of food, smell and taste of food; 
fear that occurs when eating, such as dysphagia; and fear of swallowing food ${ }^{10-12}$. The distinctive difference from other eating disorders is that in ARFID there are psychological disorders, such as anxiety and lack of parenting ${ }^{13,14}$.

Health promotion is an effort to empower individuals, groups and communities to maintain, improve and protect health ${ }^{15}$. In addition, to achieve a perfect degree of health, both physical, mental and social, the community must be able to recognize, realize their aspirations and needs and be able to change or overcome their environment ${ }^{16}$. The form of health promotion carried out by mothers to children is to improve health by adhering to strategies for monitoring healthy behavior in children. If the lifestyle that is lived by parents is a healthy one, the behavior that will be applied to children will also be a healthy lifestyle, one aspect of which is to get children to eat on time ${ }^{17}$.

\section{Method}

Research Design and Setting: A cross-sectional design was used. This study was conducted at the 6 places in Malang Regency, Indonesia.

Respondents and Sampling: The respondents were recruited from five different health centers using simple random sampling method. The population included all families with ARFID children. A total of 245 families with ARFID children voluntary participated in the study and completed all questionnaires.

Instruments: The data collection tools were single questionnaires on demographic characteristic designed by the researcher. The demographic data included mother's age, level of education, mother's occupation, family income, number of children, children's age, children's sex, height, and weight. Tools for parental engagement consisted of eight items, namely: parenting; help feed children; accompany the child while playing, urinating and defecation; giving opinions to children; parents communicating with each other regarding children's needs and communicating actively with children.

Data Collection: The data collection was assisted by eight research assistants. A questionnaire packet was completed with a description of the study, consent procedure, response confidentiality, and the researcher's contact details.
Data Analysis: Original data were inputted into an excel spreadsheet and checked by the researcher. All data were analyzed using IBM SPSS 23.0 statistics. Descriptive analysis included frequency, percentages, means and the standard deviation was used to provide descriptive data. Data were analyzed using the chi-square technique and regression test. In this study, the statistical level of significance was set at $\mathrm{P}<0.05$.

\section{Result}

Most of the mothers were in the age range of 26-35 years (56.7\%). Most mothers' education was high school $(36.3 \%)$ and not working (77.6\%). Income was mostly between 1-2 million/month (51.4\%) with the number of children $1(42.4 \%)$ respondents. The maximum age of toddlers was $\leq 3$ years $(72.2 \%)$. The sex of most children was female $(55.1 \%)$. The nutritional status of children was at normal height $(60.8 \%)$.

Table 1 shows the results that parental engagement was related to the mother's age $(p=0.007)$. Engagement between parents had no relation to level of education $(\mathrm{p}=0.243)$, mothers' occupation $(\mathrm{p}=0.062)$, family income $(p=0.127)$, occupation of parents $(p=0.924)$, income of parents $(\mathrm{p}=0.542)$, and number of children $(p=0.924)$. The health promotion behavior was related to the level of the mother's education $(p=0.007)$, a number of children $(\mathrm{p}=0.008)$, and height of children $(\mathrm{p}=0.019)$. The strongest indicator of parental engagement was in parents communicate with each other regarding children's needs, with the average of 4.37 ( $S D \pm 0.952$ ), while the weakest engagement in fulfilling the needs of children was to help children defecate, with the average $2.85(\mathrm{SD} \pm 1.172)$.

Table 1: Relationship between demographic data with parental engagement and health promotion behavior

\begin{tabular}{|c|c|c|}
\hline \multirow{2}{*}{ Characteristics } & \multicolumn{2}{|c|}{ p-value } \\
\cline { 2 - 3 } & Engagement & $\begin{array}{c}\text { Health promotion } \\
\text { behavior }\end{array}$ \\
\hline $\begin{array}{c}\text { Mother's age } \\
\text { (years) }\end{array}$ & 0.007 & 0.124 \\
\hline $\begin{array}{c}\text { Level of } \\
\text { Education }\end{array}$ & 0.127 & 0.007 \\
\hline Occupation & 0.924 & 0.839 \\
\hline Income & 0.542 & 0.112 \\
\hline $\begin{array}{c}\text { Number of } \\
\text { Children: }\end{array}$ & 0.924 & 0.008 \\
\hline
\end{tabular}


Table 2: The indicators of parental engagement and health promotion behavior

\begin{tabular}{|c|c|c|}
\hline No. & Indicators & Mean $( \pm$ SD $)$ \\
\hline \multirow[t]{9}{*}{1.} & \multicolumn{2}{|l|}{ Parental engagement } \\
\hline & Parenting & $3.84( \pm 1.129)$ \\
\hline & Help feed children & $3.45( \pm 1.125)$ \\
\hline & Accompany the child while playing & $3.56( \pm 0.972)$ \\
\hline & Helping children when urinating & $3.12( \pm 1.074)$ \\
\hline & Helping children when defecating & $2.85( \pm 1.172)$ \\
\hline & Giving opinions to children & $4.13( \pm 1.008)$ \\
\hline & Parents communicate with each other regarding children's needs & $4.37( \pm 0.952)$ \\
\hline & Communicate actively with children & $4.33( \pm 0.927)$ \\
\hline \multirow[t]{12}{*}{2.} & \multicolumn{2}{|l|}{ Health promotion behavior } \\
\hline & Ask questions about health & $3.78( \pm 1.131)$ \\
\hline & Complete assignments about health & $3.95( \pm 1.108)$ \\
\hline & Perform early screening & $3.84( \pm 1.123)$ \\
\hline & Get help from health professionals & $3.67( \pm 1.218)$ \\
\hline & Doing consistent living activities & $3.87( \pm 1.008)$ \\
\hline & Eliminating unhealthy behavior & $3.84( \pm 1.108)$ \\
\hline & Conduct health behaviors on your own initiative & $3.86( \pm 1.047)$ \\
\hline & Recommended health behavior & $4.55( \pm 0.709)$ \\
\hline & Use leading health information & $4.19( \pm 0.974)$ \\
\hline & Explain strategies to optimize health & $3.91( \pm 1.100)$ \\
\hline & Looking for help when needed & $3.81( \pm 1.166)$ \\
\hline
\end{tabular}

Table 3 shows that the regression model of health promotion behavior was 31.653 and parental engagement was 0.392. The regression coefficient value of the Parental Engagement variable was 0.392 . This value showed an increase that occurs in the Health Promotion Behavior variable if Parental Engagement increases. The $t_{\text {count }}$ was 4.647 with a significance value of 0.000 . The value of $t_{\text {table }}$ at free degree 243 and the real level of $5 \%$ was 1.970 . Because the value of $t_{\text {count }}$ was greater than $t_{\text {table }}$ or the significance value was smaller than the real level of $5 \%$, it was concluded that there was a significant effect of parental engagement on promotive behavior with a positive direction of influence.

Table 3: The influence of parental engagement in improving health promotion behavior

\begin{tabular}{|c|c|c|c|c|c|c|c|c|}
\hline & \multicolumn{2}{|c|}{$\begin{array}{l}\text { Unstandardised } \\
\text { Coefficients (B) }\end{array}$} & \multirow{2}{*}{$\begin{array}{c}\text { Standardised } \\
\text { Coefficients } \\
(\beta) \\
\end{array}$} & \multirow{2}{*}{$T_{\text {count }}$} & \multirow{2}{*}{ P Value } & \multirow{2}{*}{$\mathbf{R}^{2}$} & \multicolumn{2}{|c|}{$\begin{array}{l}\text { 95\% Confidence } \\
\text { Interval }\end{array}$} \\
\hline & B & Std. error & & & & & Lower & Upper \\
\hline (Constant) & 31.653 & 2.552 & & \multirow{2}{*}{4.647} & \multirow{2}{*}{0.000} & \multirow{2}{*}{0.082} & \multirow{2}{*}{1.94} & \multirow{2}{*}{2.08} \\
\hline Parental Engagement & 0.392 & 0.084 & 0.286 & & & & & \\
\hline
\end{tabular}

The correlation coefficient (r) was 0.286 , which means that there was a strong relationship between parental engagement and health promotion behavior. The coefficient of determination (R2) obtained was 0.082 , which means that health promotion behavior was influenced by parents' engagement of $8.2 \%$, while the remaining $91.8 \%$ was influenced by factors other than parental engagement.

\section{Discussion}

Parental engagement can be influenced by the mother's age. Age was an indicator of maturity, the older they get, the more knowledge and experience they have about appropriate behavior to educate children. Ages that were too young or too old cannot perform this role optimally because physical and psychological strength was needed; besides affecting physical aspects, 
the mother's age also affects the psychological aspects of the mother because a mother who is too young is not ready to become a mother in terms of her child care skills. This young mother emphasizes her youthful nature rather than her motherly nature ${ }^{18}$. Children with young parents will get more relaxed supervision because younger parents tend to have a high tolerance and tolerate children more ${ }^{19}$.

Communication between parents and children can be seen as an effort to monitor, know and direct children's development. Open communication will make children feel valued, loved and cared for by their parents. The existence of effective and efficient communication, carried out continuously, can create intimacy, openness and more attention between the couple and parents are more aware of developments in children, both physically and psychologically ${ }^{20}$. Parents who become good listeners will have a better relationship with their children $^{21}$. New ways of communicating with children must be based on respect and skill ${ }^{22}$. This contains two meanings, namely greetings should not hurt the self-esteem of children and parents must first show an understanding attitude to children, then give advice.

Health promotion behavior can be influenced by the level of education, a number of children and the condition of the child (height and age). Families with higher education levels will find it easier to receive health information specifically on how to educate toddlers on a daily basis. Children need strong support from their families; if family support for children is good, then the children's growth and development will be stable ${ }^{23}$. Education will have an impact on the mindset and views of parents in educating their children. Parents who have a high level of education and insight will pay attention to and care for their children according to their age of development and will show better personal and social adjustments that will make children have a positive outlook on others and society ${ }^{24}$. This healthcare includes prevention and self-protection from diseases and other health problems, improving health and seeking healing if sick $^{25}$

Thing which can be an obstacle to parental involvement in children's education are parental education levels, parental work conditions, past experience in education, parental inferiority feelings and other personal problems, such as distance from home to schools, culture and language ${ }^{26}$. Characteristics of parents of toddlers, which include age, education, and work, can influence the process of behavior change. This shows that the average age of respondents is in the age of healthy reproduction when being self-motivated to obtain as much knowledge as possible. Health promotion is a form of an effort to improve maternal and child health that aims to reduce maternal and child mortality in a sustainable manner, by increasing community independence in the field of maternal and child health ${ }^{27}$. The high rate of maternal and child mortality is one of the problems that occur in Indonesia in the health sector, as a result of the low level of the economy and public education in the health sector.

\section{Conclusion}

Good engagement between parents will reduce tension when providing care for children who experience ARFID. The higher the level of stress in parents will increase behavior problems in children. The good parental engagement was influenced by the age factor of parents. Maturity possessed by the mother causes the ability to provide care and pay attention to the good nutritional status of children. The most dominant indicator of parental engagement was communication between husband and wife related to the needs of the child. Health promotion behavior was influenced by maternal education level, number of children and the nutritional status of children. There was a significant influence between parental engagement and increasing health promotion behavior.

Ethical Clearance: Ethical approval was obtained from the ethics committee of the Public Health, Universitas Airlangga number 333- KEPK.

\section{Source of Funding: Self-funding}

\section{Conflict of Interest: None.}

\section{REFERENCES}

1. Septiani D, Nasution IN. Peran Keterlibatan Ayah dalam Pengasuhan Bagi Perkembangan Kecerdasan Moral Anak. J Psikol. 2018;13(2):120-5.

2. Savage JS, Rollins BY, Kugler KC, Birch LL, Marini ME. Development of a theory-based questionnaire to assess structure and control in parent feeding (SCPF). Int J Behav Nutr Phys Act. 2017;14(1):9. 
3. DeMaris A, Mahoney A, Pargament KI. Fathers' contributions to housework and childcare and parental aggravation among first-time parents. Fathering. 2013;11(2):179.

4. Alligood MR. Nursing theorists and their work. Elsevier Health Sciences; 2017.

5. Damayanti N. Hubungan Peran Orangtua Dengan Perilaku Picky Eater Pada Balita Di Posyandu Rw 1 Notoprajan Wilayah Kerja Puskesmas Ngampilan Yogyakarta. J Appl Microbiol. 2015;119(3):859\{ \textendash\}867.

6. Nabuasa CD, Juffrie M, Huriyati E. Riwayat pola asuh, pola makan, asupan zat gizi berhubungan dengan stunting pada anak 24-59 bulan di Biboki Utara, Timor Tengah Utara, Nusa Tenggara Timur. J Gizi dan Diet Indones (Indonesian J Nutr Diet. 2016;1(3):151-63.

7. Purwandari E. Model Kontrol Sosial Perilaku Remaja Berisiko Penyalahgunaan NAPZA. Universitas Gadjah Mada; 2015.

8. Wang G, Divall S, Radovick S, Paige D, Chen Z, Ji Y, et al. Prevalence and Community Variation in Harmful Levels of Family Conflict Witnessed by Children: Implications for Prevention. 2015;311(6):587-96.

9. Davies W, Satter E, Berlin KS, Sato AF, Silverman $\mathrm{AH}$, Fischer EA, et al. Reconceptualizing feeding and feeding disorders in interpersonal context: the case for a relational disorder. J Fam Psychol. 2006;20(3):409.

10. Nicely TA, Lane-Loney S, Masciulli E, Hollenbeak CS, Ornstein RM. Prevalence and characteristics of avoidant/restrictive food intake disorder in a cohort of young patients in day treatment for eating disorders. J Eat Disord. 2014;2(1):21.

11. Kostro K, Lerman JB, Attia E. The current status of suicide and self-injury in eating disorders: a narrative review. J Eat Disord. 2014;2(1):19.

12. Fisher MM, Rosen DS, Ornstein RM, Mammel KA, Katzman DK, Rome ES, et al. Characteristics of avoidant/restrictive food intake disorder in children and adolescents: a "new disorder" in DSM-5. J Adolesc Heal. 2014;55(1):49-52.

13. Kenny MC, Ward-Lichterman M, Abdelmonem MH. The Expansion and Clarification of Feeding and Eating Disorders in the DSM-5. Prof Couns Res Pract. 2014;4(3).
14. Strandjord SE, Sabik J, Nahra A, Abdulkader Z, Sieke EH, Worley S, et al. Avoidant/Restrictive Food Intake Disorder: Treatment Choice and Outcome in the Outpatient Setting. J Adolesc Heal. 2016;58(2):S37-8.

15. Efendi F, Makhfudli M. Keperawatan Kesehatan Komunitas Teori dan Praktik dalam Keperawatan. Jakarta: Salemba Medika; 2009.

16. Huriah T. Metode Student Center Learning : Aplikasi pada pendidikan Keperawatan Ed.Pertama. Jakarta: Prenadamedia Group; 2018.

17. Soekidjo N. Promosi Keshatan dan Perilaku Kesehatan. edisi revisi 2012. Jakarta PT Rineka Cipta. 2012;

18. Isrowati SN, Keb M, Mat S. PERBEDAAN PERAN AYAH DAN PERAN IBU DALAM MEMBERIKAN PENDIDIKAN SEKS ANAK PRA PUBERTAS DI DUSUN KALIABU GAMPING SLEMAN YOGYAKARTA. Universitas' Aisyiyah Yogyakarta; 2017.

19. Statistics FIF on C and F. America's Children in Brief: Key National Indicators of Well-Being, 2010. ERIC Clearinghouse; 2010.

20. JULIYANTO N. PENGARUH KOMUNIKASI ORANG TUA DENGAN ANAK TERHADAP PERILAKU ANAK DI DESA GADUNG (Studi di Desa Gadung Kecamatan Toboali Kabupaten Bangka Selatan). FKIP Unpas; 2017.

21. Mufidah H. Komunikasi antara orang tua dengan anak dan pengaruhnya terhadap perilaku anak:(studi kasus di SMP Islam Al-Azhar 2 Pejaten Jakarta Selatan). 2008;

22. Alex S. Komunikasi Orang Tua-Anak. Bandung: Angkasa. 1996;

23. KemenKes RI. Profil data kesehatan Indonesia tahun 2011. Jakarta Kementeri Kesehat Republik Indones. 2012;

24. Shonkoff JP. Building a new biodevelopmental framework to guide the future of early childhood policy. Child Dev. 2010;81(1):357-67.

25. Notoatmodjo. Ilmu Perilaku Kesehatan. Jakarta: Rineka Cipta; 2010.

26. Diadha R. Keterlibatan Orang Tua dalam Pendidikan Anak Usia Dini di Taman KanakKanak. Edusentris. 2015;2(1):61-71.

27. Indah G, Rachim HA, Irfan M. Promosi Kesehatan Ibu dan Anak melalui Corporate Social Responsibility (CSR) Bidang Kesehatan Ibu dan Anak. Share Soc Work J. 2014;4(2). 